\title{
Outstanding Teachers: The Steps In Acquiring Them
}

\author{
Rusi Rusmiati Aliyyah ${ }^{1, a^{*}}$, Widyasari1,b, Rasmitadila1,c, Megan Asri Humaira1,d, Sri Wahyuni Ulfah',e Didi Mulyadi²,e \\ ${ }^{1}$ Department of Elementary School Teacher Education, Universitas Djuanda Bogor, Indonesia \\ ${ }^{2}$ STIE Pertiwi Management Faculty Bekasi, Indonesia \\ a rusi.rusmiati@unida.ac.id; b widyasari@unida.ac.id; c rasmitadila@unida.ac.id; d megan.asri@unida.ac.id; c wahyuniulfah@gmail.com; \\ ddidi.mulyadi@pertiwi.ac.id \\ *Corresponding Author \\ Whatsapp Number: [08176395090 ]
}

How to Cite : Aliyyah, R., R., Widyasari, W., Rasmitadila, R., Humaira, M., A., Ulfah, S., W., \& Mulyadi, D. (2019). Outstanding Teachers: The Steps In Acquiring Them. International Journal for Educational and Vocational Studies, 1 (5), 440-447

\section{ARTICLE HISTORY}

Received: 23 June 2019

Revised: 22 July 2019

Accepted: 27 August 2019

\section{KEYWORDS}

Outstanding Teachers;

Teacher Competence;

Competition;

\begin{abstract}
Teachers are professional educators with the main task of educating, teaching, guiding, directing, training, evaluating, and evaluating students. So that it is expected to be able to produce graduates who are intelligent, qualified, competitive, noble and have noble character. The era of globalization requires high-quality teachers and is ready to compete, both at national, regional and international levels. The study aims to determine the criteria for outstanding teacher competitions in elementary schools by using a multi-site approach through schools that get national-level exceptional teachers in 2017 and 2018 in West Java, Banten and DKI Jakarta. Data collection techniques are carried out through interviews, documentation and observation, while data analysis techniques are used through data reduction, data display and conclusion drawing. The results of the study stated that the selection of outstanding elementary school teachers was intended to increase motivation, dedication, loyalty and professionalism of teachers who were expected to have a positive effect on improving performance and achievement. Criteria for selecting outstanding teachers consist of portfolio assessment, learning videos and teacher performance assessments, written tests consisting of teacher competencies and educational insights, scientific papers and scientific writing presentations.
\end{abstract}

This is an open access article under the CC-BY-SA license.

\section{INTRODUCTION}

Educational principles within countries are to produce competent graduates having able to compete in the workplace and live in a society. But the competencies themselves develop and changes as the time change. The principal goal of education in the schools should be creating men and women who are capable of doing new things, not merely repeating what other generations have done; men and women who are creative, inventive and discoverers, who can be critical and verify, and not accept, everything they are offered (Sengupta, 2016). The educational principles are aimed at developing and changing from the target of producing not only competent graduates but also critical in answering the challenges given to them in a changing society (Ganimian \& Murnane, 2016). The graduates must also be able to be inventors, creative in solving the changing challenges in society. The roles of the schools are crucial in producing those graduates as the educational qualities lie not only from the qualified teachers but also the support from the institutions or school management. Effective schools emphasize the importance of a quality teaching force in improving educational - outcomes for students. The effect of teachers on student achievement is well established. Quality teachers are one of the most important school-related factors found to facilitate student learning (Loeb, 2019).

Teachers' effects in producing competent graduates are given credit. The most crucial questions are what kind of measurement models which apply to determine the quality of the teachers objectively.(Liu, 2018). The importance of the teachers in producing competent graduates are also confirmed. The performativity agenda is accompanied by an acknowledgement of 'the teacher' as the crucial factor in the drive to raise educational standards (Sorensen, 2016).

The next question is, what kind of teachers will improve the quality of education? The simple answers shall be the ones who are competent, professional, and high achievers. To determine those qualities shall be focused on the performance appraisal concentrate on them. The teacher's performance appraisal shall be able to see the full potential they have. The performance appraisal will also determine the quality and professionalism of the teachers. It means those with 
outstanding competencies which can create the creativities and innovation aligned with the students.

The facts, not all teachers who have sound skills, creativities, and professionalism, can become high achiever teachers as the competition is very tight.. They need institution in supporting the development of them so that their potential can be explored optimally. From those challenges, the researchers come to the hypothesis that having only the competencies will not be sufficient to become high achiever teachers. Based on the above, it is necessary to develop outstanding teachers as a strategy in facilitating teachers in selecting excellent teachers both at the sub-district, district or municipal, provincial, and national levels.

To have the objective and transparent model, the outstanding teacher's criteria must be in hand to be visible to all stakeholders. This paper is intended to provide a model for acquiring national exceptional teachers from all over Indonesia. The criteria must then be understood and accessible by everyone involving in the industry.

\section{Teachers' professionalisme}

Professional teachers are those who love jobs. It means that they are working as a teacher not only to share knowledge or teaching but also how to educate students to get better. "There are three major categories on the definition of professional teachers; (a) the inter-personal, most of the traits mentioned frequently and in strong terms referred to warm student-teacher relations, respect for students and a show of consideration (b) the professional: This was seen in the behaviour of the exemplary teachers in terms of didactic skills and broad subject matter knowledge: and (c) the social-value dimensions; who transmitted moral values and provided personal examples, especially in tense situations" (Yariv \& Maskit, 2014).

Qualified teachers' categories are those able to have a warm welcome and respect their students so that there will be an understanding among them, which finally forced the students to perform the best they can. Professional teachers also have holistic knowledge which relates the experience itself with the real-life faced by the students.

Professional teachers are those that advanced professional practice is best described through the notion of 'a teacher with expertise' and that this is preferable to the term 'the expert teacher' (Sorensen, 2016).

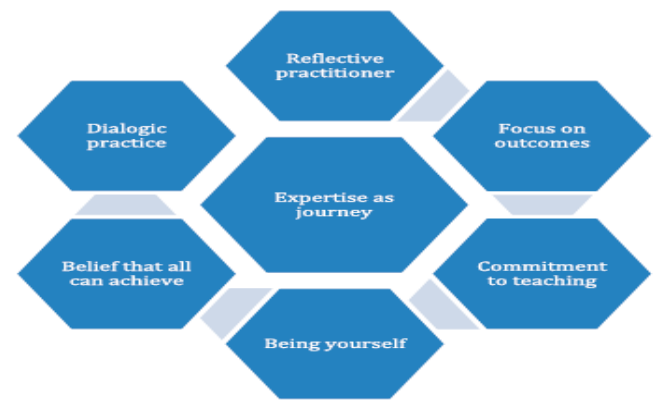

Figure 1. Professional Teachers (Sorensen, 2016)
Sorensen underlines that professional teachers are those who have: expertise as a journey; reflective practitioner, dialogic practise, focus on the outcome, committed to teaching, believe on the students, and be themselves.

To make them perform the best, the qualified teachers still need to have professional development. "Professional development is understood as representing the growth of teachers in their profession. Villegas-Remers (2003) defined it as "a long-term process that includes regular opportunities and experiences planned systematically or unplanned to promote growth and development in the profession" (Mukeredzi, 2016).

Professional development as a way to develop the ability and skills shall be supported by planned development from the institution. Teacher professionalism has been a subject of growing interest in recent years because of its emphasis on developing standards for the teaching profession and on improving the knowledge, skills, and capabilities that teachers need to meet the varying needs of students (Kilinç, 2015). Professional teachers are ones that can be left behind as the students change very rapidly. The rapid changing and various needs of society shall influence the needs of the graduates quality and outcomes.

\section{METHODS}

This research aims to find out the criteria of the outstanding assessment at elementary schools in 2018. The study uses the qualitative method with the multi-sites approach. Data collection was carried out through interviews, documentation and observation. The participants of this research are the headmasters and national level outstanding teachers in 2017 and 2018 coming from five schools at Jakarta, Banten and West Java provinces. The data were also gaine from the Directorate of Teachers and Educational Staf from the Ministry of Education and Cultures. The schools are State Elementary School 023 Pajagalan Bandung, State Elementary School 5 Sukasari Tangerang, State Elementary School 3 Menteng Jakarta, Al-Irsyad Al-Islamiyah Elementary School Bekasi and Al-Izhar Elementary School Pondok Labu Jakarta.

Data analysis consists of data reduction, display, and verification (Miles, Huberman, \& Saldaña, 2014). While data validity was carried out through credibility, transferability, dependability and accuracy. (Miles et al., 2014).

\section{RESULTS AND DISCUSSIONS}

The criteria of the outstanding teacher's assessment at the Ministry of Education and Cultures in 2018 consist of 5 aspects, namely portfolio, teaching and learning videos, written test, scientific papers and paper presentation. 


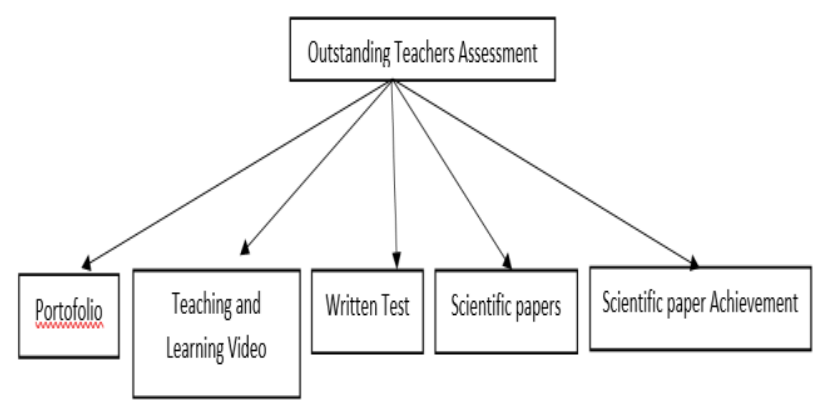

Figure 2. Outstanding Teachers Assessment Criteria

The First, portfolio assessment. The portfolio is a document consisting of information about activities followed by outstanding teachers candidates during the period of their services at the educational institutions. Portfolio documents were provided along with the statements that the data were original and authentic. The portfolio assessed include the ones of academics and non-academic components. Aspects that also include in the assessment of the portfolio document are that the candidates have been involved in training and scientific forum as facilitators or speakers. Other than that the candidates must also have teaching planning and teaching practice documents. The candidates must also show the records of the assessment form his/her superiors/headmasters at schools. Other materials needed in the portfolio are academic performances, professional development works and membership of the professional organization. The detail aspects can be seen at the below picture.

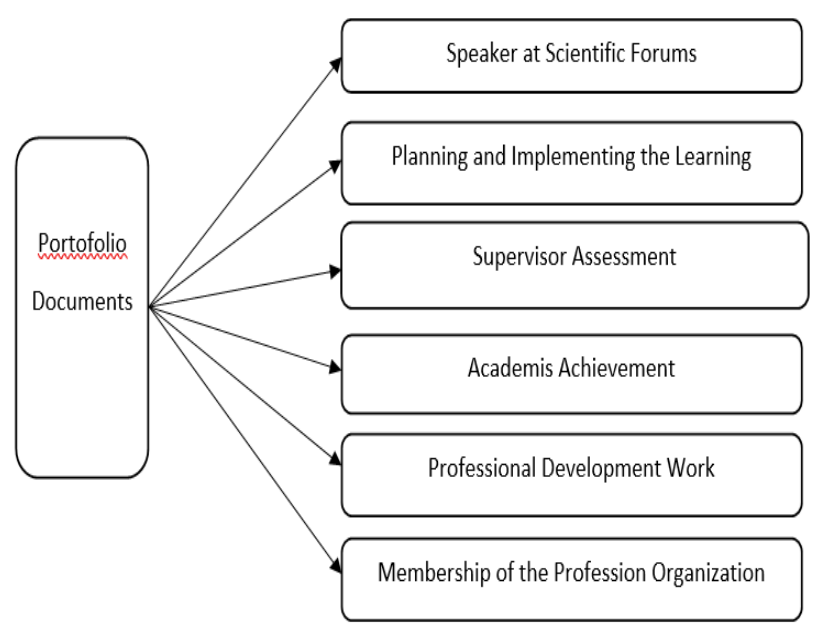

Figure 2. Portfolio Document

The portfolio is an assessment technique carried out through works outcome from teachers' candidate. It's in the term of academic and non-academic documents. The collection provides comprehensive information about what has been done by teachers for the shake of the public. The materials can be easily accessible and be put in the archives. The development of technology also helps individual and institution to manage well the documents. And so the teachers. The digital tracks of the individual and organization can be found very quickly. Currently, the report can also be put in e-portfolio. The e-Portfolio function as a storage, workspace and showcase to support Competency Certification in Indonesia (Sensuse \& Purwandari, 2018). E-portfolio is a promising approach to develop teachers into reflective practitioners who show that they can adapt to new technologies, new criteria, and new environments (Alshumaimeri, 2017). Often administrators seek alternative methods of evaluating staff while staff are frequently searching for purposes to represent the breadth and quality of their efforts. One way proving to be valid for gathering and organising products of teacher activity is the portfolio. The development of teacher portfolio requires planning, time organization, and cooperation from students, colleagues, parents, and supervisors. The format of the collection may vary from individual to individual and be based upon personal choice. Portfolios provide a useful insight into both the content and methods of instruction used by the teacher and by doing so add a significant qualitative dimension to many existing teacher evaluation systems (Gelfer, Hara, Krasch, \& Nguyen, 2015). Portfolios are one of the alternatives that can be used for writing assessment (Eridafithri, 2015). The future teacher's evaluation can be much more accessible by, for example, asking the candidates to store the whole portfolio within the bulk of storage system designed by the committee.

Secondly: Teaching and Learning Videos. It is one part of the assessment, which includes the teaching planning and practice by the outstanding teacher's candidates. The evaluation of teaching and learning videos consists of an introduction, main activities, evaluation and closing stages.

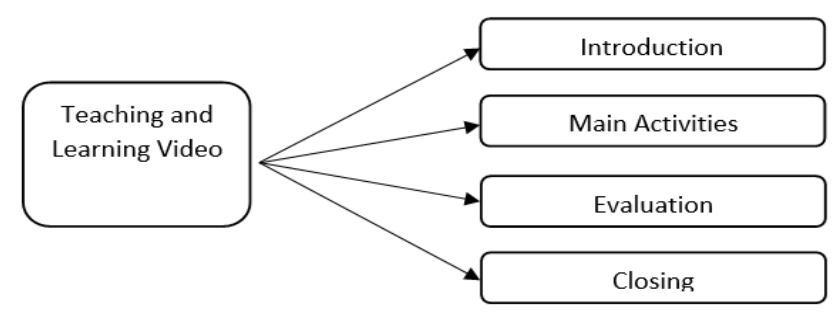

Figure 3. Assessment Components of Teaching and: earning Videos

Teachers' performance assessment is an assessment of each detail activities the candidates have already experienced, such as career development, rank, and position within the organization. The primary role of the teachers can be left from acquiring the needed knowledge and skills as teachers' academical and competency standards. The mastery of the teachers' competency shall determine the quality of the teaching and learning process. And one of the methods is the one using information technology like video in delivering the 
teaching and learning activities. This model shall create the interest of the students in following the process. This can bring students and teachers to be interactive, lovely and conducive teaching and learning processes. The use of videos can motivate teachers to benefit from technology in creating practical and fun learning activities. Thus videos can focus upon enabling teachers to use technology effectively to inquire about their students' learning progress (Luckin et al., 2016).

The teachers' assessment is a part of the development and growth of themselves. National Educational Association in Teacher assessment and Evaluation states that "The core purpose of teacher assessment and evaluation should be to strengthen the knowledge, skills, dispositions, and classroom practices of professional educators. This goal serves to promote student growth and learning while also inspiring great teachers to remain in the classroom (Cowan \& Goldhaber, 2016). While the other opinion states that "Current policy discourse about teacher evaluation is mired in a rewards-and-punishment framework that too often aims to: 1) measure the effectiveness of each teacher, 2) categorize and rank teachers, 3) reward those at the top, and 4) fire those at the bottom. Such a simplistic approach not only ignores the complexity of teaching but also overlooks the real purpose of teacher assessment and evaluation (Fantini, 2018).

The teachers' assessment can drive teachers to perform better day by day, which can result in the maximum students' achievement. Leading students' performance and provide quality learning experience has long been dreamt by the educational institution. Teachers' expertise and competencies have become the most important variables influencing the graduates' competency. So the regular teachers' performance appraisal is needed to determine the quality level of teachers. The assessment shall evaluate the gaps between the expected quality required by students and society and reality. Teacher appraisal can be a crucial lever for increasing the focus on teaching quality," and an understanding of the various aspects of successful performance appraisal is essential" (Elliott, 2015). While Performance appraisal can be defined as the ongoing process used for identifying, measuring and developing an individual's performance following an organization's strategic goals (Elliott, 2015).

Teacher Performance Appraisal in some countries can guarantee the benefit of educational systems; which included teachers, students, schools, government, and society. The teachers' performance is also influenced by the leadership styles and communication skills of the head masters. (Ahmad Gawdy Prananosa, M.Rusni Eka, Rusi Rusmiati Aliyyah, 2018). Teachers' evaluation can be the tool to measure the effectiveness of the teachers, categorize and rank them. As a result, the teachers with the best performance shall get the rewards and provide the coaching for the ones with lower performance.

Thirdly; Written Test. This written test is a part of the criteria for outstanding teachers assessment. The written test materials consist of professional, pedagogics, personality and social competencies and institutional knowledge. The mastery of the concepts of the teachers' skills can be the most crucial part of doing the written test.

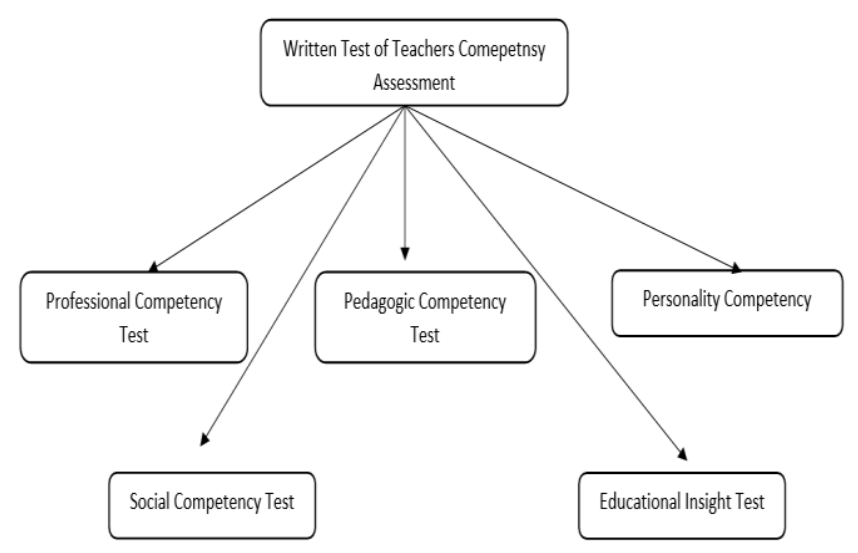

Figure 4. Written Test Assessment

These are some professional indicators which can be put as competent teachers characteristics. Teachers competences are the combination of personal, knowledge, technology, social and spiritual skilss. (Menteri Pendidikan Nasional, 2007). Those are the characters that can shape the competency standard for the teaching profession. The minimum standard for teachers profession, among others, are topics mastery, students' character understanding, educative, willingness to develop self and profesional (Mulyasa, 2009). Teachers competency can influence whether the education outcome can be achieved or not. Teachers competency are also affected by educational background, teaching experience, and length of services in the industry. (Hamzah B Uno, 2011). Teachers' competency is a reflection of qualitative value from the teachers and academic staff (Uno, 2007).

Education reform takes effect on the development of teachers' competency, growth and works. "Competencies are defined as "the set of knowledge, skills, and experience necessary for future, which manifests in activities" She also underlines that competencies as "knowledge, skills, attitudes, values, motivations and believes people need to be successful in a job." The common understanding related to teachers' competencies is divided into three main areas as field competencies, pedagogical competencies and cultural competencies. Teachers' professional skills can be composed of different dimensions other than the three main areas" (Kiymet SELVI, 2016).,Selvi underlines that professional teachers must have the following competencies; curriculum competency, lifelong learning competency, social and cultural competency, emotion competency, communication competency, ICT competence, environmental competency, field competency, and research competency (Kiymet SELVI, 2016). Once they 
become competent, they will be able to pass the initial assessment before joining the teacher's competition.

Teachers with high competencies are those who are professional and love the profession. This will make them develop and improve their knowledge, skills, and competencies by attending workshops and seminars. Competent teachers are those who provide inspiring, loving and enriching teachings. Qualified and skilled teachers are those that put students as a part of society.

Competent teachers are those who want to see teaching and training which inspires, excites and enriches learners from all parts of society, provides the skills for a modern economy and contributes to the cohesion and regeneration of local communities" (Dixon \& Pilkington, 2017).

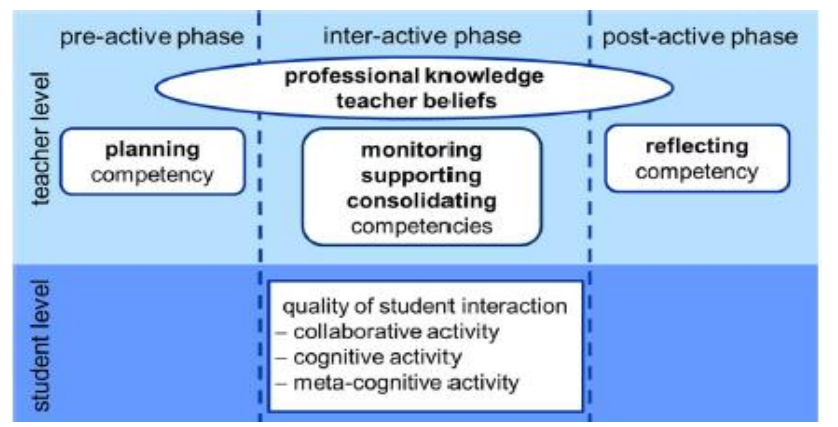

Figure 5. Teachers Competencies (Kaendler, Wiedmann, Rummel, \& Spada, 2014)

Competent teachers are those who can have at least three competencies; planning competency, monitoring, supporting, consolidating skills and reflecting skills. Planning competency is a part of a pre-active phase that most parts belong to teachers, the second ones belong to teachers part of having professional knowledge and belief while students parts; collaboration activity, cognitive activity, and metacognitive activity. While the last is post-active phase belongs to teachers, which lies on the reflecting competency (Kaendler et al., 2014). Assessments show that the different tests measure a common core of similar skills, thus providing evidence for convergent validity (Kruit et al., 2018).

Fourth; Scientific Writing Assessment. Scientifics works developed by teachers are the ones of the action research results during the teaching and learning process practice. The scientific writings shown were not the ones of theses or dissertation. The aspects included in the scientific paper must contain the followings; introduction, problem identification, problem formulations, aims of the research, methodology, analysis, conclusion, recommendation and references. Second; characteristics components of the papers shall include the originality, innovation and creativities and also the value is given to society at large. Third; application of language rules, sentence structures and words choice based on the PUEBI ( The Guidance of Indonesia Language Structures).

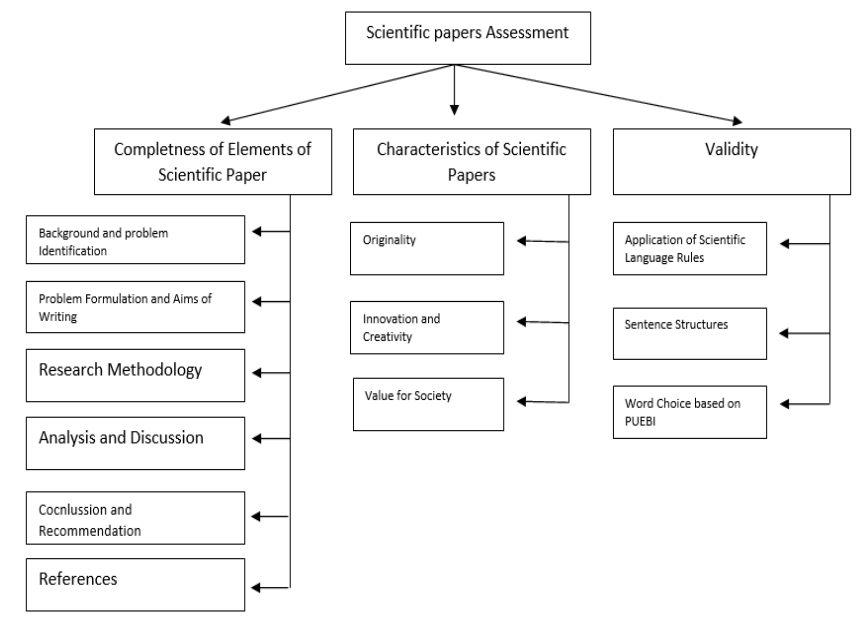

Figure 6. Scientific Writing Works Assessment

Components

Scientific Writing Works are the results of their research. The works can be in the type of research results or ideas. It is essential for them as the ability to share knowledge through written works can provide people or society to understand better what they have already done. The scientific actions can also prove that the teachers are productive. The experimental tasks are also a way for teachers to express their competence, interest, and innovation in the field of teaching and learning.scientific writing works, on the other hand, can be seen as adults' scientific literacy to measure mainly from the perspective of mastery of scientific knowledge and skills (Naganuma, 2017). The cross-case analysis revealed that despite vastly different teacher preparation programs and contexts, assignments were highly similar and focused on developing the candidates' self as a writer or on becoming a teacher of writing.

The Fifth; The assessment of the presentation of the scientific writing works which consist of 1) exposure, which includes topics mastery, attractiveness, time management, media quality and answers to the question relevance. 2)material discussed which provides for novelty, shrinkage exposure, empirical data supports, relevant theory supports, and comprehensive materials; 3) Attitude during the presentation which includes openness, confidence, natural, politeness and verbal language, 4) the paper which provides for the clarity of the ideas, paper structures, supporting data and illustration and language quality. 


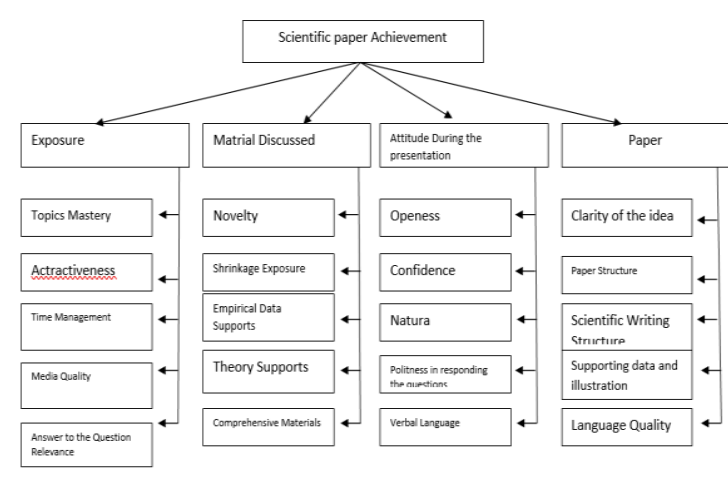

Figure 7. Components of Paper Presentation Assessment

The final process of the assessment is the delivery of the works they have already made as a way of dissemination to the public and society. This step is needed as the competition of finding the most outstanding teachers must be a part of public interest. The presentation can determine the quality of the candidates in defending his/her ideas already made. This model may effectively complement the existing approaches to teach critical scientific thinking (Ferenc, Cerven, Birc, \& Sevc, 2017). The presentation or the ability to deliver the idea can result in the knowledge of scientific thinking skills. Among others are question-posing, explanation, graphing, inquiry, and metacognition (Dori, Zohar, Carmi, Zohar, \& Carmi, 2018). The delivery is also showing that the skill of argumentation is recognized as a crucial factor for teacher success in school and beyond. The ability to integrate knowledge and ideas, delineate and evaluate claims and arguments, and assess the reasoning used in cases is central to the Common Core State Standards (Frey, Ellis, Bulgren, Hare, \& Ault, 2015).

The Sixth; Exemplary. The assessment of exemplary and attitude was carried out through two different questionnaires, excellent and opinion surveys. The respondents of the studies are headmasters 5 teachers and ten students from the schools where the candidates are from. The assessment includes excellent scores from headmasters, colleagues and students.

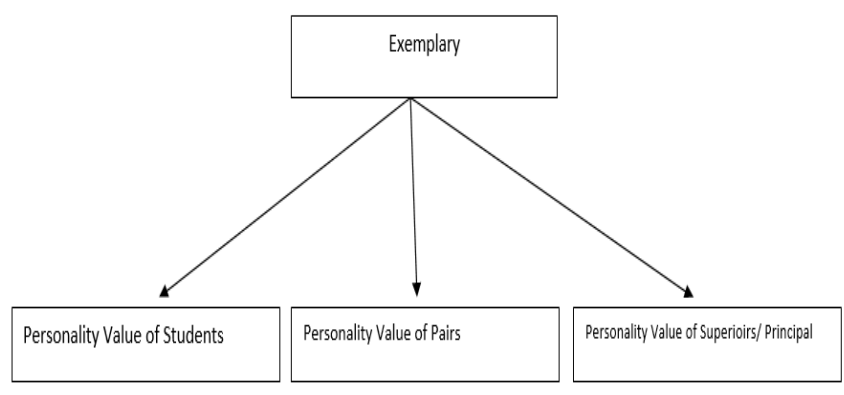

Figure 8. The Component of Exemplary Assessment

The last, the procedures of the assessment for those competing at the national level in 2018 were started with the evaluation on the portfolio documents, teachers performance, teaching and learning videos, scientific writings, and exemplary questionnaires were taken from students. The candidates of the national outstanding teacher's competition must also attend the written tests which consist of professional and personality competencies and institutional knowledge. After that, the candidates must make the presentation of his/her paper. The scoring will then be put in the available format and counted based on the determined weight. And finally, the committee ranks the candidates based on the overall components.

This character is the right attitude done by teachers, i.e. politeness, discipline, achievement-oriented, and showing the belief to God. The word of exemplary is an easy thing to speak, but it is challenging to carry out as it needs a lot of courage. Exemplary is 'the walk the talk' model from the teacher in which by doing a good thing, his/her students will do the same. Besides that, if the teachers are the ones who like talking without doing, it would be challenging to influence students. What makes a leadership preparation program exemplary? All three excellent programs featured in this unique issue evidence strong learning orientations and more sustained improvement work in their pursuit of excellent preparation (Cosner, 2018). The exemplary can also be seen as the ability of the teachers to give an example. They are also the ones who are warm, discipline, honest, tolerant, and respectful. (Aliyyah, 2014). That exemplary teachers hold asset-oriented beliefs about bilingualism and diversity, viewing DLL children and families as knowledgeable resources to the community. With these beliefs as a foundation, teachers enact a vast repertoire of practices tailored for DLL children, including fostering relationships and belonging through embedding home languages and cultural practices in the classroom; emphasizing guided play, co-constructed curriculum, and ongoing observational assessment; and scaffolding and teaching the English language. Implications for teaching and teacher education are discussed (Baker, 2018).

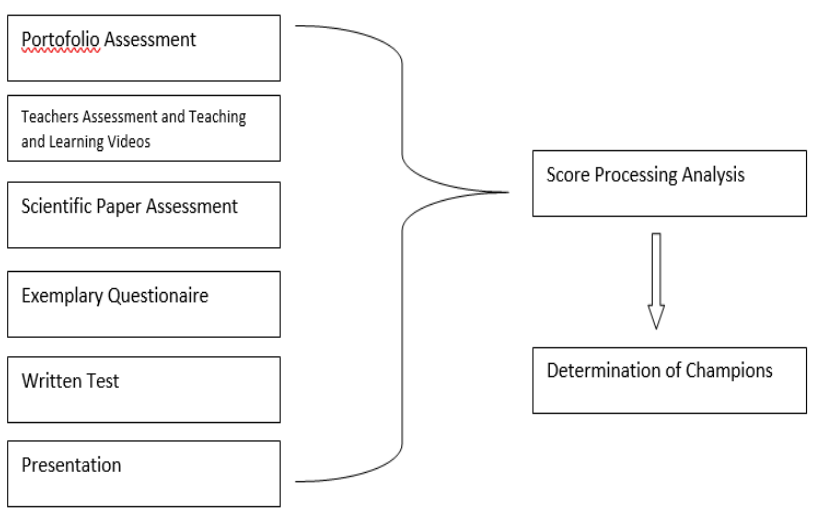

Figure 9. Assessment Procedures

\section{CONCLUSION}

Outstanding teachers could not be produced only from holding a competition. But it should be understandable by 
teachers that becoming exceptional teachers is a need as a way to develop and respect the profession. Becoming outstanding doesn't mean as the pride of only for themselves but more than that it is because they are responsible for the quality of education and students. Quality students should be the main aims of becoming outstanding teachers. Outstanding teachers mean that they respect the profession by not stopping to develop and improve their quality. But comprehensive cooperation among parties involving in the business can create cultural development in making the outstanding teachers. Finally, the word of exceptional teachers is not only a part of the result of the competition but because the culture and the needs to develop human resources through education.

\section{Acknowledgements}

The researcher would like to thank the Directorate of Research and Community Service Directorate General of Research and Development. Ministry of Research, Technology and Higher Education of the Republic of Indonesia to provide funding to finance the Penelitian Terapan Unggulan Perguruan Tinggi (Higher Education Applied Research) grant.

\section{REFERENCES}

Ahmad Gawdy Prananosa, M.Rusni Eka, Rusi Rusmiati Aliyyah, A. Y. (2018). Pengaruh Gaya Kepemimpinan dan Keterampilan Berkomunikasi Kepada Sekolah Terhadap Kinerja Guru. Journal of Administration and Educational Management, 1, 63-74.

Aliyyah, R. R. (2014). Penyelenggaraan Pendidikan Berbasis Karakter Dan Teknologi Dalam Mengatasi Tantangan Globalisasi (Studi Kasus Di Smk Wikrama Kota Bogor) the Education Implementation Based on Character and Technology Toward the Globalisation Challenge (a Case Study Resear. Jurnal Sosial Humaniora, 5(1).

Alshumaimeri, Y. A. (2017). Teacher Electronic Portfolio and its Relation to EFL Student Teacher Performance and Attitude. International Journal of Education \& Literacy Studies, 5(1). https://doi.org/10.7575/aiac.ijels.v.5n.1p.42

Baker, M. (2018). Playing , Talking , Co-constructing: Exemplary Teaching for Young Dual Language Learners Across Program Types. Early Childhood Education Journal, O(0), 0. https://doi.org/10.1007/s10643-018-0903-0

Cosner, S. (2018). What Makes a Leadership Preparation Program Exemplary? Journal of Research on Leadership Education, (Mc 147), 1-18. https://doi.org/10.1177/1942775118819661

Cowan, J., \& Goldhaber, D. (2016). National Board Certification and Teacher Effectiveness: Evidence From Washington State. Journal of Research on Educational Effectiveness, 9(3), 233-258. https://doi.org/10.1080/19345747.2015.1099768
Dixon, F. J., \& Pilkington, R. (2017). Teaching in Higher Education Poor relations? Tensions and torment; a view of excellence in teaching and learning from the Cinderella sector. Teaching in Higher Education ISSN: 2517(May). https://doi.org/10.1080/13562517.2017.1301912

Dori, Y. J., Zohar, A., Carmi, M., Zohar, A., \& Carmi, M. (2018). Gender-fair assessment of young gifted students' scientific thinking skills. International Journal of Science Education, O(0), 1-26. https://doi.org/10.1080/09500693.2018.1431419

Elliott, K. (2015). Teacher Performance Appraisal : More about Performance or Development? Australian Journal of Teacher Education, 40(9).

Eridafithri. (2015). The Application of Portfolios to Assess Progress in Writing of EFL Students at Secondary Schools in Banda Aceh. Studies In English Language And Education, 2, 1-16.

Fantini, A. E. (2018). Teacher Assessment and Evaluation. The TESOL Encyclopedia of English Language Teaching, 1-11. https://doi.org/10.1002/9781118784235.eelt0652

Ferenc, J., Cerven, F., Birc, E., \& Sevc, A. (2017). Intentionally Flawed Manuscripts as Means for Teaching Students to Critically Evaluate. Biochemistry and Molecular Biology Education Resistance, 1-9. https://doi.org/10.1002/bmb.21084

Frey, B. B., Ellis, J. D., Bulgren, J. A., Hare, J. C., \& Ault, M. (2015). Development of a Test of Scientific Argumentation. Electronic Journal of Science Education, 19(4).

Ganimian, A. J., \& Murnane, R. J. (2016). Improving Education in Developing Countries: Lessons From Rigorous Impact Evaluations. Review of Educational Research, 86(3), 719-755. https://doi.org/10.3102/0034654315627499

Gelfer, J., Hara, K. O., Krasch, D., \& Nguyen, N. (2015). Teacher portfolios : an effective way to assess teacher performance and enhance learning. Early Child Development and Care, (March 2015), 37-41. https://doi.org/10.1080/03004430.2015.1005614

Hamzah B Uno. (2011). Profesi kependidikan. Jakarta: Bumi Aksara.

Kaendler, C., Wiedmann, M., Rummel, N., \& Spada, H. (2014). Teacher Competencies for the Implementation of Collaborative Learning in the Classroom: a Framework and Research Review. Educ Psychol Rev. https://doi.org/10.1007/s10648-014-9288-9

Kilinç, A. C.. (2015). The Relationship Between Teacher Leadership, Teacher Professionalism, and Perceived Stress. Eurasian Journal of Educational Research, (58), 1-26.

Kiymet SELVI. (2016). Teachers ' Competencies Teachers' Competencies. Teachers' Competencies That, VII(January 2010), 167-176. https://doi.org/10.5840/cultura20107133

Kruit, P. M., Oostdam, R. J., Berg, E. Van Den, Schuitema, J. A., Kruit, P. M., Oostdam, R. J., ... Schuitema, J. A. 
(2018). Assessing students ' ability in performing scientific inquiry : instruments for measuring science skills in primary education. Research in Science \& Technological Education, 5143, 1-27.

https://doi.org/10.1080/02635143.2017.1421530

Liu, J. (2018). Constructing resource sharing collaboration for quality public education in urban China: Case study of school alliance in Beijing. International Journal of Educational Development, 59(September 2017), 9-19.

https://doi.org/10.1016/j.ijedudev.2017.09.004

Loeb, S. (2019). Effective Schools: Teacher Hiring, Assigment, Development dan Retention. Association For Education Finance and Plolicy, 7(3).

Luckin, R., Clark, W., Avramides, K., Hunter, J., Luckin, R., Clark, W., ... Oliver, M. (2016). Using teacher inquiry to support technology- enhanced formative assessment: a review of the literature to inform a new method assessment: a review of the literature to inform a new method. Interactive Learning Environments ISSN:, 4820(January).

https://doi.org/10.1080/10494820.2015.1121152

Menteri Pendidikan Nasional. (2007). Standar Kualifikasi Akademik dan Kompetensi Guru (pp. 1-32). Kementerian Pendidikan Nasional Republik Indonesia.

Miles, M. B., Huberman, M. A., \& Saldaña, J. (2014). Qualitative Data Analysis. A Methods Sourcebook. Zeitschrift Für Personalforschung, 28(4), 485-487. https://doi.org/10.1136/ebnurs.2011.100352

Mukeredzi, T. G. (2016). Teacher Professional Development Outside the Lecture Room: Voices of Professionally Unqualified Practicing Teachers in Rural Zimbabwe Secondary Schools. Global Education Review, 3(4), 84-106.

Mulyasa. (2009). Standar Kompetensi dan Sertifikasi Guru. Remaja Rosda Karya.

Naganuma, S. (2017). An assessment of civic scientific literacy in Japan: development of a more authentic assessment task and scoring rubric. International Journal of Science Education, 8455(May), 1-23. https://doi.org/10.1080/21548455.2017.1323131

Sengupta, M. A. (2016). Teaching Excellence and Innovative Practices: A Case Study of National Awardee Teachers of India. Journal of Education and Practice, 7(1), 48-53.

Sensuse, D. I., \& Purwandari, B. (2018). Defining e-Portofolio Factor for Competency Certification using Fuzzy Delphi Method. TOJET: The Turkish Online Journal of Educational Technology, 17(2), 25-33.

Sorensen, N. (2016). Professional Development in Education Improvisation and teacher expertise : implications for the professional development of outstanding teachers professional development of outstanding teachers. Professional Development in Education, 5257(March).

https://doi.org/10.1080/19415257.2015.1127854
Uno, H. B. (2007). Model Pembelajaran. Jakarta: Bumi Aksara.

Yariv, E., \& Maskit, D. (2014). Exemplary Teachers ' Influence on Their Adolescent Pupils Who Later Became Teachers. Journal of Education and Training Studies, 2(1), 88-97.

https://doi.org/10.11114/jets.v2i1.244 